\title{
Co-infection with Border Disease Virus and Brucella melitensis in an Aborted Sheep Foetus
}

\author{
Murat Şevik ${ }^{1}$, Yasin Gülcü̈², Müge Doğan ${ }^{1}$ \\ ${ }^{1}$ Department of Molecular Microbiology, Veterinary Control Institute, Konya, Turkey \\ ${ }^{2}$ Department of Bacteriology, Veterinary Control Institute, Konya, Turkey
}

Geliş Tarihi / Received: 18.09.2017, Kabul Tarihi / Accepted: 10.11.2017

\begin{abstract}
In this study, we investigated the potential roles of BDV and Brucella melitensis infections in a case of sheep abortion. Internal organ specimens from aborted sheep foetus and EDTA whole blood sample from mother of the foetus were collected from a sheep flock in the Konya Province in the Central Anatolia region of Turkey in 2017. The presence of Brucella spp. directly assessed by bacterial isolation and detection of BDV was carried by real time RT-PCR. Genetic characterization of the BDV field isolate was conducted by sequencing the 5'- end untranslated region (UTR) region of BDV. Brucella strain was isolated from the samples of aborted sheep foetus, and it was identified as Brucella melitensis by biochemical characteristics, agglutination with monospecific A and M sera. BDV RNA was detected in EDTA whole blood sample and aborted sheep foetus. Phylogenetic analysis in 5'-UTR region allocated the field isolate of BDV obtained in this study into BDV-7 genotype. To the best of our knowledge, this is the first report on the dual infection of aborted sheep foetus with BDV and Brucella melitensis.
\end{abstract}

Key words: Abortion, Border disease virus, Genetic characterization, Brucella melitensis, Sheep

\section{Bir Koyun Abort Fötusunun Border Disease Virusu ve Brucella melitensis ile Koenfeksiyonu}

\begin{abstract}
Özet: Bu çalışmada, bir koyun abort vakasında border disease virusu (BDV) ve Brucella melitensis enfeksiyonlarının potansiyel rolleri araştırılmıştır. İki bin on yedi yılında Türkiye'nin İç Anadolu Bölgesinde yer alan Konya İlindeki bir koyun işletmesinden, bir abort koyun fötusuna ait iç organ örnekleri ve fötusun annesinden EDTA'lı tam kan örneği elde edilmiştir. Brucella spp. varlığı bakteriyel izolasyon, BDV ise real time RT-PCR yöntemi ile araştırılmıştır. BDV'unun genetik karakterizasyonu, 5'- translate olmayan bölge sonunun (UTR) sekans analizi ile gerçekleştirilmiştir. Abort koyun fötusundan izole edilen Brucella suşu biyokimyasal karakteri ve monospesifik A ve M serumları ile aglütinasyonuna bağlı olarak Brucella melitensis olarak identifiye edilmiştir. Koyun abort fötusunda ve EDTA'lı kan örneğinde BDV tespit edilmiştir. Filogenetik analiz sonucu, bu çalışmada izole edilen BDV saha suşunun BDV-7 genotipinde olduğu belirlenmiştir. Bizim bildiğimiz kadarıyla, bu çalışma koyun fötusunun BDV ve Brucella melitensis ile birlikte enfeksiyonu hakkındaki ilk rapordur.
\end{abstract}

Anahtar Kelimler: Yavru atma, Border disease virus, Genetik karakterizasyon, Brucella melitensis, Koyun

\section{Introduction}

Border disease (BD) is a reproductive disease of sheep, and occasionally seen in goats. The clinical manifestations of the disease are infertility, abortion, mummified foetuses, stillbirths, and the birth of 'hairy-shaker' lambs and persistent infections of the offspring [9]. The causative agent of disease, border disease virus (BDV), classified in the genus Pestivirus of the Flaviviridae family, and is closely related to bovine virus diarrhea viruses (BVDV $1,2)$ and classical swine fever virus (CSFV) [6]. BDV can also infect cattle, chamois and pigs $[1,8]$. Transmission of BDV mainly occurs by horizontal and vertical routes, and weak lambs can be persistently infected (PI) [2].

Ovinebrucellosis is another economically important disease of small ruminants that causes reproductive problems such as infertility and abortions. B. melitensis is the main etiological agent of brucellosis in small ruminants. The main clinical signs of B. melitensis infection in small ruminants are abortion and stillbirths, which usually occur during the last two months of gestation following infection [3]. The current study was conducted to investigate occurrence of BDV and B. melitensis in the case of small ruminant abortion. 


\section{Material and Methods Collection of samples}

An aborted sheep foetus was submitted to the Konya Veterinary Control Institute from a sheep flock in the Konya Province in the Central Anatolia region of Turkey in 2017. According to farmer' report, flock had a history of barren ewes, birth of small weak lambs with hairy fleeces, and abortions occurred at 2 to 3 months of gestation. The rate of abortion in this flock was $15 \%(24 / 160)$. Foetal stomach contents and liver of the aborted foetus were collected. Furthermore, whole blood sample from mother of the foetus and internal organ specimens of aborted foetus were collected for BDV detection.

\section{Bacteriological examinations}

Samples from stomach contents and liver of the aborted foetus were inoculated onto Farrell's medium $(5-10 \% \mathrm{v} / \mathrm{v}$ sterile inactivated horse serum) (Oxoid, SR0035) supplemented with Brucella selective supplement (Oxoid, SR083A). After incubation of the plate at $37^{\circ} \mathrm{C}$ and $5 \% \mathrm{CO}_{2}$ conditions for 7 days, the observed colonies were investigated and identified as Brucella spp. by morphological, cultural and characteristics. The strain was biotyped by agglutination with monospecific $\mathrm{A}$ and $\mathrm{M}$ antisera. Samples were also inoculated onto Campylobacter agar base with selective supplement (Oxoid, SR069E) and 7\% defibrinated sheep blood and MacConkey agar for isolation of other bacterial agents.

\section{RNA extraction and reverse transcription- polymerase chain reaction (RT-PCR)}

Viral RNA extracted from the buffy coat cells from whole blood sample and organ specimens of aborted foetus using a QIAamp Cador Pathogen Mini Kit (Qiagen, Hilden, Germany). A quantitative realtime RT-PCR described by La Rocca and Sandvik [7] was used to detect BDV RNA. Amplification of part of the 5'- end untranslated region (UTR) was carried out for samples in one step RT-PCR using primers 324 and 326 [11].

\section{Sequence and phylogenetic analysis}

PCR products were purified from gels with a High Pure PCR Product Purification Kit (Roche Diagnostics, Indianapolis, USA), and sequenced on an ABI 3130x1 DNA Analyser (Applied Biosystems, USA). Phylogenetic tree was constructed with the programme MEGA software version 6, based on the evolutionary distances between different sequences calculated by Kimura two-parameter model. The confidence of the neighbour-joining tree was assessed by bootstrapping, using 1000 replicates, and only values above $50 \%$ are reported.

\section{Results \\ Bacteriological isolation}

In this study, Brucella was isolated from aborted sheep foetus. Brucella strain was identified as $B$. melitensis by biochemical characteristics and agglutination with monospecific $\mathrm{A}$ and $\mathrm{M}$ antisera. Other bacterial agents were not detected in the investigated foetus.

\section{Detection of BDV}

BDV RNA was detected in the investigated foetus and EDTA whole blood sample from mother of the foetus

\section{Sequence analyses}

A $100 \%$ level of identity was observed between the deduced amino acid sequences of the two isolates, from foetus and its mother, in the present study, whereas the similarity with sequences from different regions ranged from $67.8 \%$ to $96 \%$, lowest with United States isolate (890) highest with Turkish isolate (Aydin-04).

\section{Discussion}

In this study, Brucella was isolated from aborted sheep foetus, and identified as B. melitensis. The rate of abortion in $B$. melitensis positive flock was $15 \%(24 / 160)$. This rate is consistent with the findings of previous studies in which it has been reported that rate of abortion in $B$. melitensis positive flocks ranged between $6 \%$ and $45 \%[4,5]$.

Border disease virus can cause abortion in pregnant small ruminants [9]. In this study BDV RNA was detected in the investigated foetus. To the best of our knowledge, this is the first report on the dual infection of aborted sheep foetus with BDV and B. melitensis. It has been reported that foetal death may occur at any stage of gestation, but is 
more common during the first 2 months of gestation [12]. In this study abortion occurred at 2 to 3 months of gestation. This situation can be explained by the period of infection, immune status of the host and the virulence of virus.

Phylogenetic analysis has been used to determine the subgenotypes of field isolates from different areas of the world. The most frequent genetic classification is based on a comparison of nucleotide sequences from the 5'UTR [1,10]. The phylogenetic analysis of 5'UTR sequences typed the field isolate in this study as BDV and clustered within the BDV-7 isolates together previously characterized Turkish isolates (Figure 1). The circulation of BDV7 genotype in Turkey was also reported in previous study [10]. Results show that BDV-7 genotype is in circulation in Turkey.

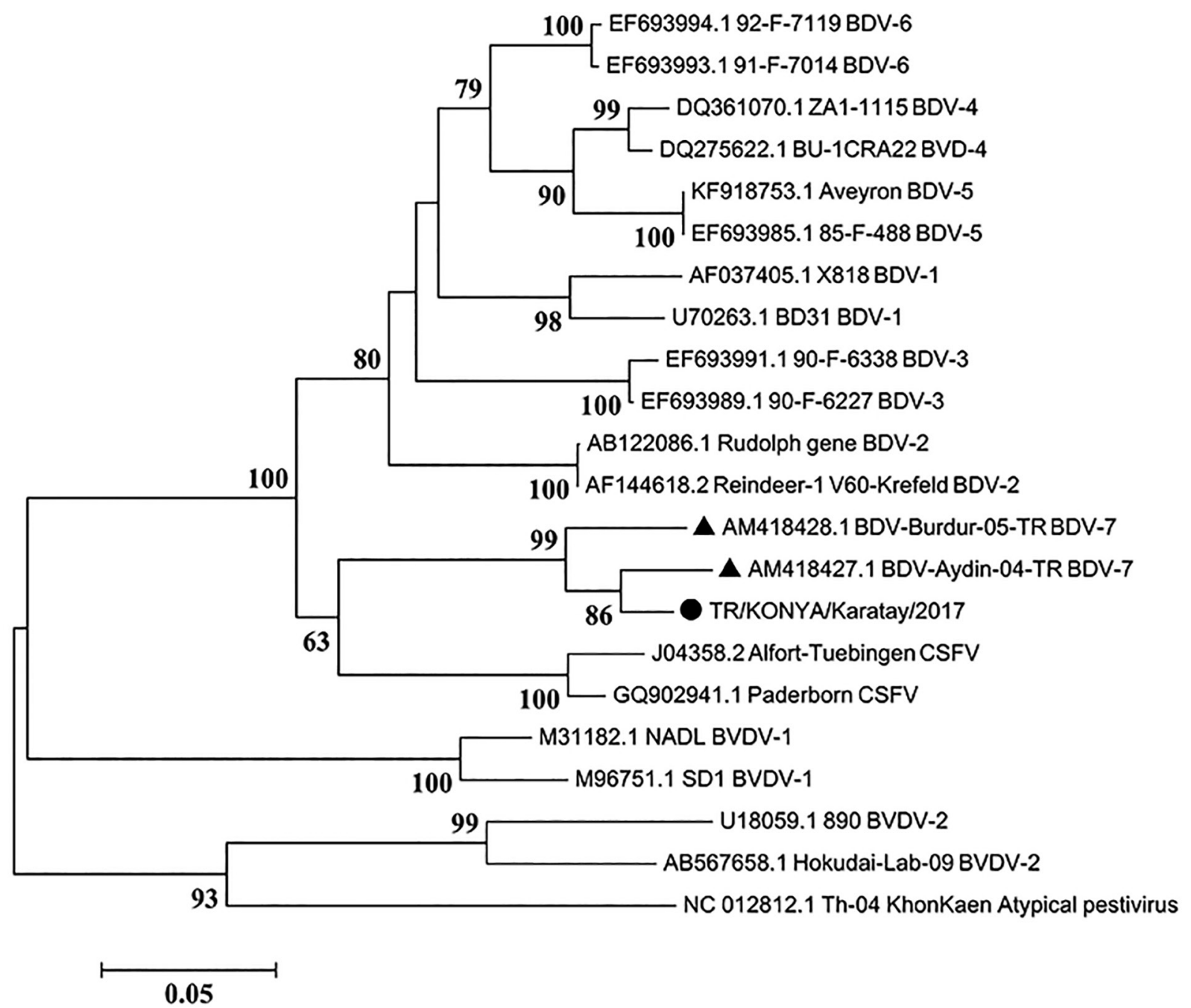

Figure 1. Phylogenetic tree constructed based on nucleotide sequences of the 5'UTR region (246 bp) showing the genetic relationships between BDVs of Turkey and other virus isolates. The sequence obtained in this study is marked with round black spot $(\bullet)$ and previous Turkish isolates are marked with black triangle $(\boldsymbol{\Delta})$.

The results of this study indicate that dual infection with BDV and $B$. melitensis can occur in small ruminant abortion cases. BDV and B. melitensis infections cause important economic losses due to reproductive failure in affected animals. Therefore, abortion cases should be examined for these two diseases. 


\section{References}

1. Becher P, Orlich M, Shannon AD, Horner G, König M, Thiel HJ, (1997). Phylogenetic analysis of pestiviruses from domestic and wild ruminants. J Gen Virol. 78, 1357-1366.

2. Cabezón O, Rosell R, Velarde R, Mentaberre G, Casas-Díaz E, Lavín S, Marco I, (2010). Border disease virus shedding and detection in naturally infected Pyrenean chamois (Rupicapra pyrenaica). J Vet Diagn Invest. 22, 744-747.

3. Díaz Aparicio E, (2013). Epidemiology of brucellosis in domestic animals caused by Brucella melitensis, Brucella suis and Brucella abortus. Rev Sci Tech. 32, 43-51, 53-60.

4. European Commission, Health \& Consumers DirectorateGeneral (2012). Eradication programme for Sheep and Goat Brucellosis (B. Melitensis). Erişim adresi: https:// ec.europa.eu/food/sites/food/files/safety/docs/cff_animal vet-progs_2012_dec-2011-807-ec_ov-cap-brucellosis_grc. pdf, Erişim tarihi: 08.08.2017

5. Hawari AD, (2012). Epidemiological Studies, Seroprevalance and Some Risk Factors of Brucellosis in Sheep and Goats in the South Province of West Bank. Asian J Anim Vet Adv. 7, 535-539.

6. Heinz FX, Collett MS, Purcell RH, Gould EA, Howard CR, Houghton M, Moormann RJM, Rice CM, Tiehl HJ, (2000). Family Flaviviridae, Virus Taxonomy. Seventh Report of the International Committee on Taxonomy of Viruses. San Diego: Academic Pres, p. 859-878.
7. La Rocca SA, Sandvik T, (2009). A short target real-time RT-PCR assay for detection of pestiviruses infecting cattle. J Virol Methods. 161, 122-127.

8. Marco I, Lopez-Olvera JR, Rosell R, Vidal E, Hurtado A, Juste R, Pumarola M, Lavin S, (2007). Severe outbreak of disease in the southern chamois (Rupicapra pyrenaica) associated with border disease virus infection. Vet Microbiol. 120, 33-41.

9. Nettleton PF, Gilray JA, Russo P, Dlissi E, (1998). Border disease of sheep and goats. Vet Res. 29, 327-340.

10. Oguzoglu TC, Tan MT, Toplu N, Demir AB, Bilge-Dagalp S, Karaoglu T, Ozkul A, Alkan F, Burgu I, Haas L, GreiserWilke I, (2009). Border disease virus (BDV) infections of small ruminants in Turkey: a new BDV subgroup? Vet Microbiol. 135, 374-379.

11. Vilcek S, Herring AJ, Herring JA, Nettleton PF, Lowings JP, Paton DJ, (1994). Pestiviruses isolated from pigs, cattle and sheep can be allocated into at least three genogroups using polymerase chain reaction and restriction endonuclease analysis. Arch Virol. 136, 309-323.

12. Office International des Epizooties (OIE), (2017). Border Disease. In Manual of Diagnostic Tests and Vaccines for Terrestrial Animals. OIE, Paris, 1-13. Available at: http:// www.oie.int/fileadmin/Home/eng/Health_standards/ tahm/2.07.01_BORDER_DIS.pdf (accessed on 25 August 2017). 